The Canadian Journal of Higher Education La revue canadienne d'enseignement supérieur

Volume XXXV, No. 3, 2005 pages 57 - 81

\title{
Enhancing Reflective Teaching Practices: Implications for Faculty Development Programs
}

\author{
HARRY HUBBALL, JOHN COLLINS \& DANIEL PRATT \\ University of British Columbia
}

\begin{abstract}
Reflecting on one's teaching practice is often an implicit goal for faculty development programs. Yet very little has been documented how programs for diverse groups of university teachers actually engage faculty in such reflection. This paper examines how theoretical constructs of reflective practice were applied in the context of an 8-month UBC Faculty Certificate Program on Teaching and Learning in Higher Education (FCP). The Teaching Perspectives Inventory (TPI) was particularly useful for providing faculty cohort members with a means of looking more deeply at the underlying values and assumptions that constituted their philosophical orientations to teaching. Furthermore, a change in faculty members' TPI scores indicate that participants reflected more comprehensively on their teaching at the end of the program, than they did at the beginning of the program. Barriers to facilitating reflection included inadequate time allocation, unclear expectations and goals for reflection activities, and varying cultural norms for reflective teaching practices within academe.
\end{abstract}




\section{RÉSUMÉ}

Réfléchir sur sa propre pratique d'enseignement est souvent un objectif implicite des programmes de développement du corps professoral. Il existe cependant à ce jour très peu de recherches documentées sur la manière dont les programmes établis pour divers groupes d'enseignants universitaires engagent véritablement le corps professoral dans une telle réflexion. Ce document examine la manière dont les concepts théoriques de la pratique réflective ont été appliqués dans le contexte d'un UBC Faculty Certificate Program on Teaching and Learning in Higher Education (FCP Programme de certificat du corps professoral de l'UBC sur l'enseignement et l'apprentissage dans l'enseignement supérieur) de huit mois. L'Inventaire des perspectives de l'enseignement (TPI) a été particulièrement utile pour fournir aux membres de la cohorte du corps professoral les moyens d'étudier plus en profondeur les valeurs et hypothèses sous-jacentes qui ont constitué leurs orientations philosophiques sur l'enseignement. De plus, la modification des scores TPI des membres du corps professoral indique que les participants ont réfléchi de manière plus détaillée sur leur enseignement à la fin du programme qu'au début du programme. Les barrières qui empêchaient la facilitation de la réflexion comprenaient une attribution de temps inadéquate, des attentes et objets peu clairs pour les activités de réflexion ainsi que des normes culturelles variables pour les pratiques d'enseignement réflectif au sein du monde universitaire.

\section{INTRODUCTION}

There is a growing recognition of the need for university faculty to reflect on their teaching (Boyer, 1990; Brew \& Boud, 1996; Cranton, 2001; Cunsolo, Elrick, Middleton, \& Roy, 1996; McKeachie, 1997; Rust, 1998). Reflecting on one's teaching, it is argued, should foster personal growth and development as a university teacher, lead to better understanding how students learn, help faculty members assess which practices are effective in specific circumstances, aid in the development of responsive curricula, and enhance the scholarship of teaching and learning (Altrichter, Posch, \& Somekh, 1995; Joy \& Johnson, 2002; Kreber, 2001; Loughran 2002;

The Canadian Journal of Higher Education Volume XXXV, No. 3, 2005 
Mills, 2000; Schön, 1987). The call to reflective practice in universities and colleges is fast becoming an integral part of the process of tenure and promotion. As a result, professors are now routinely expected to reflect on their role and mission as teachers (Pratt, 2002).

In response to this, many universities in Australia, the UK and Europe have instituted faculty development programs with the explicit mission of helping faculty members reflect on their teaching practice (Baum \& Baum, 1996; Gibbs, 1998; Keesen, Wubbels, Van Tartwijk, \& Bouhuijs, 1996). Yet, very little has been published about whether and how programs that are intended for diverse groups of university teachers actually engage faculty in such reflections.

This paper examines how theoretical constructs of reflective practice were applied in the context of an eight-month Faculty Certificate Program on Teaching and Learning in Higher Education (FCP) at the University of British Columbia.

\section{Toward a working definition of 'reflection on teaching'}

While there is general agreement that reflection can have a positive effect on teaching, there is less agreement about what reflection means in practice and how it differs from simply engaging in workshops or training programs intended to improve the act of teaching or the development of curricula. One of the clearest writers on reflective practice in teaching is Stephen Brookfield. In his book, Becoming a Critically Reflective Teacher (1995) he introduces the idea thus:

Reflective practice has its roots in the Enlightenment idea that we can stand outside of ourselves and come to a clearer understanding of what we do and who we are by freeing ourselves of distorted ways of reasoning and acting... American pragmatism is present in the reflective tradition's emphasis on making practice attentive to context, and in its disdain for standardized models of good teaching. (pp. 214-15)

Two ideas are crucial in this statement: First, that reflective practitioners examine not only the how and what of their teaching, they also examine the underlying premises on which they base their work; and second, that 


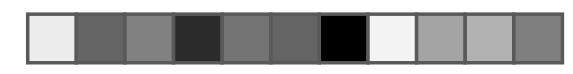

reflective practitioners assume a plurality of models of 'good teaching'. Both ideas are central to how theoretical constructs of reflective practice were applied in the UBC Faculty Certificate Program on Teaching and Learning in Higher Education (FCP) under review in this article.

In reviewing the concept of "reflection", it is clear that this term requires clarification and an analysis of theory-practice integration. The term 'reflection' should not become what Brookfield calls a 'premature ultimate', that is, a concept that once invoked, stops any critical debate dead in its tracks. Smyth (1992) supports this caution by warning that the term reflection "runs the real risk of being totally evacuated of all meaning" (p. 285) as a result of its use as a reference to any and all activities directed at improving teaching. As Brookfield says:

One problem with the reflective practice idea is that it has become a catch-all term... The terms reflection and reflective practice are now so overused that they are in danger of becoming buzzwords denuded of any real meaning - of taking on the status of [a] premature ultimate, like motherhood or democracy. (p. 216)

Thus in this paper, the authors use the term 'reflection' to mean thoughtful consideration and questioning of what we do, what works and what doesn't, and what premises and rationales underlie our teaching and that of others. The authors do not assume that improving how one teaches always necessitates reflection. The authors do assume, however, that reflection on one's teaching is likely to raise the question of how one teaches and, in the end, to have a positive effect on the improvement of teaching.

\section{Application of reflective learning practices: The UBC Faculty Certificate Program on Teaching and Learning in Higher Education (FCP)}

Each year faculty members from a wide range of academic ranks and disciplines at the University of British Columbia apply for one of twenty-four places in the FCP. Each faculty cohort has limited enrolment which increases opportunities for cross-disciplinary collaboration and

The Canadian Journal of Higher Education

Volume XXXV, No. 3, 2005 
critical reflection. The FCP is now in its sixth year. Graduating faculty include groups of both experienced and novice teachers, national and institutional teaching award winners, senior and junior faculty from across nine different faculties (schools) and some thirty departments at the UBC campus. The aim of the FCP is to enhance the scholarship of teaching and learning at UBC through an eclectic range of carefully designed learning experiences (Hubball \& Poole, in press). On completion of the FCP, faculty are expected to be able to:

1. Develop a critically reflective teaching practise.

2. Think critically about curriculum and pedagogical issues in higher education.

3. Articulate their own values and beliefs about teaching and learning.

4. Rrecognise the value of inclusion, student equity and diversity issues.

5. Design responsive courses and assess student learning using a variety of methods.

6. Facilitate active learning, critical thinking \& problem-solving skills.

7. Use a variety of communication, teamwork and leadership skills.

\section{Guiding principles for reflective learning experiences}

There is no lack of advice on how faculty members might be encouraged to reflect on their teaching practices (Angelo \& Cross, 1993; Mills, 2000; Schön, 1987; Seijts, Taylor, \& Latham, 1998; Yost, Sentner, \& FoulonzaBailey, 2000). Faculty certificate programs such as the one reviewed here tend to involve people from diverse contexts of practice, including a range of disciplines, years of experience, sizes of classes and settings for learning and teaching. No advice, nor any technique for facilitating reflection, is universally helpful. Each must be considered a tool to be selected, adapted and integrated into the individual person of the teacher, the nature of their teaching, the learners they teach and the settings within which they must work. Advice and strategies for reflection on practice must, therefore, be considered in the context of those faculty who would use it and the programmatic conditions that press upon the implementation of reflective practices, both within the program and without (Barab \& Duffy, 2000; 
Harper, 1996; Hubball, Clarke \& Beach, 2004; Pratt, 1997). To deal with this uncertainty and complexity, we identified four assumptions and associated implications for facilitating reflection:

- Reflection requires an explicit rationale and criteria for critical analysis. Therefore, it will be important to provide structure and guidance in helping people engage in reflective activities.

- Reflection should be an on-going, integral part of the program. Therefore, each activity should be linked to other activities in the program, building toward a summative document or activity that helps integrate reflective activities.

- Reflection is enhanced when it is an individual, collaborative and contextually-bound process. Therefore, the program should involve a balanced mix of individual and group activities, all of which should be authentically related to the participants' actual teaching contexts.

- Though intended to be useful to all, reflective activities will be differentially helpful to participants. Therefore, we must accept that individuals will vary in their preference for, and ability to use, each of the reflective activities.

These guiding principles were instrumental in the development of reflective learning experiences within the context of the FCP. Over the course of eight months, for example, and based on prior learning assessment, each faculty member followed an individual learning plan that combined theory, practice, collaboration and critical reflection as an integral part of working toward the FCP goals. A wide range of methods of reflection was designed to respond to the diverse needs and circumstances of each faculty member and to the overall learning objectives. Table 1 shows the range and character of reflective activities that cohort members were required to complete during the FCP. Some activities will be familiar to readers (developing a course syllabus or teaching dossier), while others maybe less familiar (Teaching Perspectives Inventory, FCP Scholarship of Teaching Scale). It is not possible within the scope of this article to go into detail about every reflective activity. However, the mix of activities was designed to complement each other and to activate reflection in a variety of ways, to help participants thoughtfully reconsider their teaching and to raise the question of the underlying premises that guided their teaching.

The Canadian Journal of Higher Education Volume XXXV, No. 3, 2005 


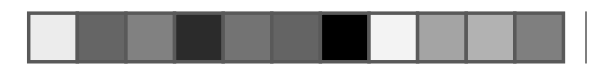

Enhancing Reflective Teaching Practices

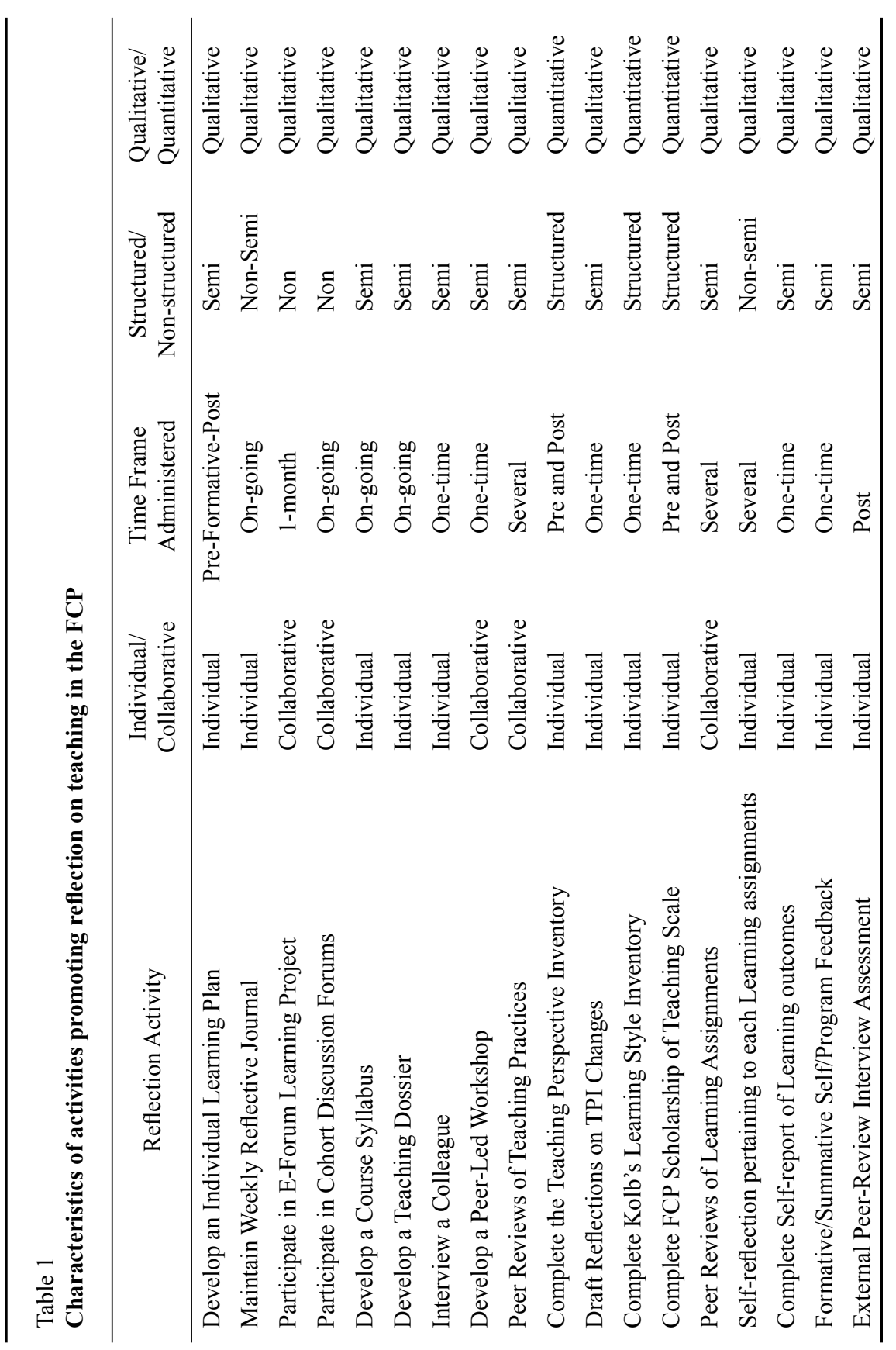

The Canadian Journal of Higher Education Volume XXXV, No. 3, 2005 
Based on weekly readings and interactive learning experiences, for example, cohort members were required to complete journal reflections that contributed to the on-going development of their teaching dossiers. A teaching dossier contained a comprehensive record of a faculty member's teaching and learning philosophy, teaching accomplishments, a critical analysis of teaching practices, and goals for continuing professional development. The development of this teaching dossier was an iterative process requiring substantive self-reflection (Bowman, 1997; Day, Robberecht, \& Roed, 1996; O'Neil \& Wright, 1998; Smith, 1995). All teaching dossiers were reviewed periodically by peer cohort members, and by external reviewers (ex-graduates of the FCP) in order to provide further constructive feedback (Hinett \& Thomas, 1999; Wildman et al, 2000).

Cohort members also completed standardized questionnaires that required faculty members to rate or rank their abilities, preferences, beliefs, actions, and/or intentions pertaining to a wide range of teaching and learning issues. The most useful of these instruments was the Teaching Perspectives Inventory (TPI). The TPI is available on-line and provided participants with an analysis of their philosophical orientations to teaching. The TPI proved to be particularly helpful in assisting participants to develop philosophy statements on teaching which were required as part of their teaching dossiers, as well for developing a deeper understanding of their own (and others) perspectives on university teaching.

\section{The Teaching Perspectives Inventory}

A perspective on teaching is an inter-related set of beliefs and intentions that gives direction and justification to our teaching actions (Pratt, 1998). It is a lens through which educators view their work. Thus, university teachers may not be aware of their perspective because it is something they look through, rather than at, when teaching. A perspective on teaching is, therefore, a way of being.

Within the Teaching Perspectives Inventory there are five perspectives: Transmission, Apprenticeship, Developmental, Nurturing and Social Reform (Pratt \& Collins, 2000). Each perspective is a singular blend of actions, intentions and beliefs and is presented as a legitimate way of thinking about adults as learners, the process of learning, the content to

The Canadian Journal of Higher Education Volume XXXV, No. 3, 2005 
be learned, and the context within which learning and teaching are to take place (e.g., numbers of students, level of course, elective versus required course, assessment procedures).

An Item analysis on the TPI confirmed high test-retest reliabilities (0.88) and internal scale consistencies (alpha $=0.79)($ Pratt \& Collins, 2000). Further research is on-going to determine the validity of the TPI against alternative indicators for teaching perspectives in higher education. Based on Pratt's (1992) initial study of more than 250 teachers and supported by data from another fifteen thousand educators who have taken the Teaching Perspectives Inventory, there is reasonable evidence that most educators hold one or perhaps two perspectives as their dominant view of teaching and may only marginally identify with one or two others. Intuitively, this makes sense since perspectives are composed of fundamentally contrasting beliefs about knowledge, learning, and teaching.

The TPI proved to be a particularly helpful tool within the FCP for several reasons: (1) the TPI is a self-administering, on-line tool that yields immediate quantitative results on completion of its 45 questions, as well as a Ten-Step Interpretation Guide for respondents to use in making sense of their numerical results (2) changes in respondents' profiles can be tracked and compared over time, and (3) the TPI serves as an efficient conversation tool, useful in focusing discussion around the central elements of one's beliefs, intentions, and actions, and providing a convenient point of departure for exploring personal teaching goals, situational constraints, departmental policies, reward systems, and broad philosophical matters.

It is not the intention of the authors to suggest that the TPI alone is adequate to capture the richness and complexity of teaching perspectives. However, as one such reflective tool, the TPI does provide a useful indicator of change in the ways that teachers reflect on their teaching. As a result, its utility goes far beyond the numbers that it yields. Therefore, the TPI will be the focus of our findings and recommendations. Clearly, the potency of any single intervention is related to its particular role in the larger context of activities (table 1) meant to engender reflection. Our findings and recommendations are to be interpreted and understood with this broader context in mind. 


\section{METHOD}

Data collection strategies, focusing around the TPI, enabled the researchers to examine specific aspects of cohort members' teaching perspectives and reflection experiences within the FCP:

1. What is the distribution of teaching perspectives for cohort members in a faculty certificate program?

2. How do cohort members in this particular FCP compare with professors elsewhere?

3. Do cohort members' TPI scores change measurably as a result of the FCP?

4. Do cohort members' TPI scores converge or diversify across perspectives as a result of the FCP?

5. To what FCP experiences do cohort members' attribute any changes that occur in their pre-post TPI scores?

6. What are the barriers to facilitating reflection for a cross-disciplinary faculty cohort?

The TPI was administered to two consecutive cohorts (2001-02 and 2002-03) at the beginning and again at the end of the eight-month FCP. The TPI is structured as an instrument whose 45 questions pertaining to a faculty member's beliefs, intentions and actions are each answered on 5-point scales of either agreement (strongly disagree to strongly agree) or frequency (never to always). On completion of the FCP, faculty participants were also required to complete a semi-structured worksheet questionnaire (Bogdan, \& Biklen, 1992). The semi-structured worksheet questionnaire required each participant to review and comment on any changes between their two TPI scores, and to identify aspects of the program that may have influenced that change. The semi-structured questionnaire contained three questions: (a) What (if anything) do you notice about any changes in your TPI scores? (b) How might you relate any changes to General Program Experience? To Specific Program Experience? (c) Any other comments? Questionnaire responses were analysed using the constant comparative method for identifying common or isolated experiences (Lincoln \& Guba, 1985). The following results section and appropriate analyses are organised to address each of the above research questions (1-6).

The Canadian Journal of Higher Education Volume XXXV, No. 3, 2005 


\section{RESULTS}

\section{What is the distribution of teaching perspectives for cohort members in a faculty certificate program?}

Table 2 summarizes the TPI scores for cross-disciplinary cohort members at the beginning of the FCP. Scale scores on the five perspectives of the TPI were each summed over 9 items; three regarding Beliefs, three about Intentions, and three reflecting Actions. Thus scores for each perspective could range from a minimum of 9 to a maximum of 45 .

Across the two years' cohorts, data were available for 44 people. Tests of significance between the members of the 2001-02 cohort and the 200203 group revealed no significant differences on any of the five individual perspectives nor on their overall totals, thus observations that are true for one group were likely largely true for both groups. Furthermore, among the nineteen female and twenty-five male cohort members represented in this study, there were no statistically detectable gender differences on any of their TPI measures.

\section{Table 2}

Distribution of TPI scores for cohort members at the beginning of the FCP

\begin{tabular}{lrrrrc}
\hline Perspective & Mean & SD & Min & Max & Num \\
\hline Transmission & 32.89 & 4.24 & 19 & 40 & 44 \\
Apprenticeship & 34.18 & 4.89 & 21 & 43 & 44 \\
Developmental & 34.64 & 3.71 & 27 & 42 & 44 \\
Nurturing & 34.84 & 4.48 & 26 & 43 & 44 \\
Social Reform & 26.66 & 4.97 & 16 & 36 & 44 \\
TPI Total & 163.20 & 13.89 & 138 & 193 & 44 \\
\hline
\end{tabular}

Minimum, maximum and standard deviation scores indicate that these 44 faculty spanned the spectrum of different teaching perspective configurations and that there is no single "professor type", any more than there is any single "student type". Typically, a faculty member's TPI profile is a "stepped" mix of all five perspectives, with one perspective visibly more dominant than the others (Pratt \& Collins, 2000). Operationally, we define 'dominant' to mean any perspective score that is one standard 
deviation or more above the average of all five of an individual teacher's TPI scores; thus what is a dominant score is unique to each individual teacher and is not affected by other people's scores.

\section{How do cohort members in this particular FCP compare with professors elsewhere?}

Figure 1 (supported by table 4) illustrates how these 44 FCP cohort members contrast with averages for a large comparison group $(n=1183)$ of university teachers based, for the most part, throughout settings in the US and Canada. The dotted lines represents the general professoriate, while the dashed and continuous lines represent the pre and post teaching perspectives profiles respectively for FCP cohort members. The general shape of the FCP cohort members parallels the "W" shape of the wider comparison group. That is, moderate Transmission, lower Apprenticeship, elevated Developmental, lower Nurturing, and moderate Social Reform.

It is important to note that in addition to electing to take the TPI, the FCP cohort in contrast, is a particular professoriate group that also elected to embark on a substantial 8-month faculty certificate program aimed at enhancing the scholarship of teaching and learning. While one might assume that the distribution of teaching perspectives for a self-selected FCP cohort would differ to that of a general professoriate group, evidence suggests otherwise. Comparative data suggest that although on average, the FCP cohort scores tended to be lower across teaching perspectives, the distribution of TPI profiles between the two groups were quite similar.

\section{Do cohort members' TPI scores change measurably as a result of the FCP?}

As expected, there was a certain degree of attrition-participants who did not continue for the full duration of the 8-month FCP or cohort members who took the TPI at the outset but failed to take the followup version. Across the two years' cohorts, data were available for 44 people at first administration and for 30 of them at follow-up time. Table 3 presents considerable detail about before-and-after perspective scores that were derived from the TPI using the 30-person matched subset for whom both pre- and post scores were available. Figure 1 illustrates that at post-program, the same "W" shape was evident and was elevated on all

The Canadian Journal of Higher Education Volume XXXV, No. 3, 2005 
Figure 1. TPI Scores for the General Professoriate, as well as Cohort Members over Time

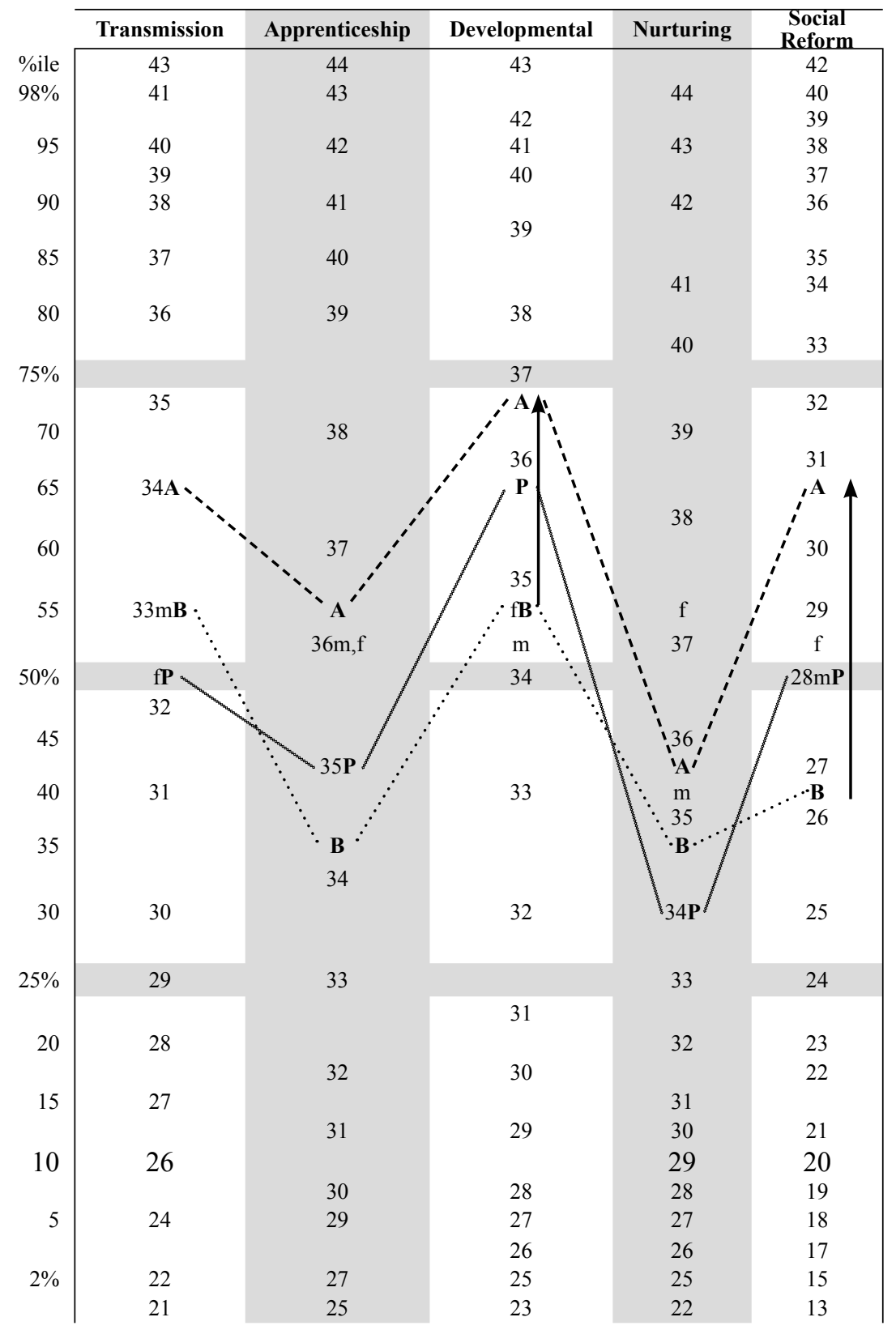

The Canadian Journal of Higher Education Volume XXXV, No. 3, 2005 
five perspectives for the FCP cohort, emphasizing that change was the rule rather than the exception.

These data suggest that the various FCP reflective activities did promote an expanded conceptualisation of teachers' views of their professional roles. Statistically significant increases resulted for Transmission, Apprenticeship, Developmental, Social Reform, and Total Score during the program. Only Nurturing showed no statistical change. Three-point increases in Developmental scores were particularly interesting because of that perspective's focus on cultivating "deep" (as opposed to surface) learning and promoting more comprehensive and penetrating thought processes among learners-precisely the same skills as critical reflection about one's teaching. Similarly, the 4-point gains in Social Reform suggests that these faculty came to acknowledge that there are value-implications to all aspects of teaching and learning in higher education.

\begin{tabular}{|c|c|c|c|c|c|}
\hline $\begin{array}{l}\text { Table } 3 \\
\text { Pre- and post pro }\end{array}$ & TP & es fo & coho & embe & \\
\hline & Pre & & Post & Gain & Significance \\
\hline & $(\mathrm{n}=30)$ & $<$ matched $>$ & $(\mathrm{n}=30)$ & $30 / 30$ & $30 / 30$ \\
\hline Transmission & 32.73 & & 33.90 & 1.17 & .042 \\
\hline Apprenticeship & 34.80 & & 36.33 & 1.53 & .032 \\
\hline Developmental & 34.93 & & 37.67 & 2.73 & .001 \\
\hline Nurturing & 35.23 & & 35.80 & 0.57 & ns \\
\hline Social Reform & 26.93 & & 30.93 & 3.50 & .000 \\
\hline Teaching Beliefs & 54.80 & & 57.67 & 2.86 & .010 \\
\hline Teaching Intentions & 56.63 & & 59.60 & 2.97 & .001 \\
\hline Teaching Actions & 53.20 & & 57.27 & 4.01 & .001 \\
\hline TPI Total & 164.63 & & 174.53 & 9.90 & .000 \\
\hline TPI Std Dev. & 4.21 & & 3.70 & 0.50 & $(.064)$ \\
\hline \# No Dominant & 0 & & 1 & +1 & --- \\
\hline \# 2+ Dominant & 6 & & 9 & +3 & --- \\
\hline
\end{tabular}

Embedded in the structure of the TPI are sub-scores gauging the strength of certain teaching Beliefs, explicitness of Intentionality, and frequency of certain Actions. Each of these sub-scores also increased over the duration of the FCP course - again suggesting an expanded mindfulness of how and why these teachers went about their instructional duties. In short, the

The Canadian Journal of Higher Education

Volume XXXV, No. 3, 2005 
11-point increase in the TPI overall total from pre to post suggests that participants became more willing to assert their Beliefs, to declare their Intentions, and to manifest their Actions, or to 'own' their 'positionality' as university teachers.

\section{Do cohort members' TPI scores converge or diversify across perspectives as a result of the FCP?}

Table 4 shows a summary of FCP participants' patterns of dominant TPI perspectives for all 44 cohort members, then pre-/post program scores for the subset of the 30 individuals for whom matched pairs were available.

\begin{tabular}{|c|c|c|c|c|c|c|c|c|}
\hline \multicolumn{9}{|l|}{$\begin{array}{l}\text { Table } 4 \\
\text { Patterns of }\end{array}$} \\
\hline & Trns & Appr & Devl & Nurt & SRef & None & Two + & Num \\
\hline FCP All Pre- & $20 \%$ & $32 \%$ & $32 \%$ & $39 \%$ & $0 \%$ & $2 \%$ & $25 \%$ & 44 \\
\hline $\begin{array}{l}\text { FCP Matched } \\
\text { Pro- }\end{array}$ & 13 & 33 & 33 & 40 & 0 & 0 & 20 & 30 \\
\hline $\begin{array}{l}\text { FCP Matched } \\
\text { Post }\end{array}$ & 10 & 33 & 53 & 27 & 0 & 2 & 30 & 30 \\
\hline $\begin{array}{l}\text { Reference } \\
\text { Professors }\end{array}$ & 17 & 33 & 41 & 28 & 4 & 7 & 28 & 1,183 \\
\hline
\end{tabular}

All perspectives (except Social Reform) were represented as dominant by one or more FCP cohort members. These were also in proportions that were largely congruent with professors elsewhere. The absence of any dominant perspective was somewhat rarer among these FCP cohort members than among reference professors, while the incidence of two (or more) such perspectives was about the same.

Compared to that of the general professoriate, the pre-post FCP cohort change data suggest that the FCP impacted affirmations of teaching and learning. Although there was certainly no expectation at the program's outset that any teacher should change their teaching orientation during the FCP, some did so nevertheless. Table 5 indicates the individual change in dominant perspective from pre to post FCP. Counts exceed 30 since participants could be dominant on more than one perspective. 


\begin{tabular}{lcc}
\hline $\begin{array}{l}\text { Table } 5 \\
\text { Dominant perspective migration (Pre to Post) of teaching perspectives for } \\
\text { cohort members }\end{array}$ & Pre & Post \\
\hline Transmission & 4 & 3 \\
Apprenticeship & 10 & 10 \\
Developmental & 10 & 16 \\
Nurturing & 12 & 8 \\
Social Reform & 0 & 0 \\
None & 0 & 2 \\
Multiple & 6 & 9 \\
\hline
\end{tabular}

Thirteen cohort members showed no change in their dominant teaching perspective while the majority (17) showed varying degrees of modification of their teaching perspective. Developmental clearly gained the greatest number of new adherents while Nurturing lost the greatest number. Two cohort member's profiles became sufficiently flattened that no perspective was clearly dominant by course end, indicating that they held new and more broadly distributed views. Cohort members holding multiple perspectives grew from six to nine.

Essentially, data in tables 4 and 5 suggest that the program did have a significant impact on the FCP cohort but not necessarily in predictable ways. Although some change may be attributed to participants' familiarity with the TPI instrument, by the end of the program, participants tended to become more balanced in their beliefs, actions and intentions profile from pre- to post. Furthermore, change mostly occurred from within one's original perspective (magnitude) of teaching rather than a substantial shift from one perspective to another. This suggests that cohort members generally became more assertive in their perspective of teaching as a result of the FCP.

\section{To what FCP experiences do cohort members' attribute any changes that occur in their pre-post TPI scores?}

Numerical data from the TPI cannot be causally linked to any of the specific activities (table 1) or components of the FCP. Qualitative data

The Canadian Journal of Higher Education

Volume XXXV, No. 3, 2005 
from semi-structured worksheet questionnaires and instructors' reflections were most instructive in this regard. Data were categorised into major themes that focussed on the cohort experience, FCP learning activities, and the development of a more thoughtful approach to teaching.

In general, attributions of change in pre-post TPI scores centred on engagement in more thoughtful approaches to teaching and learning within the FCP.

...the course has deepened my understanding and knowledge about teaching...reflecting immediately on how new approaches might work in my own context... having a general set of principles and higher level discussions promote in-depth reflection... the importance of learners creating their own knowledge... understanding how beliefs and values shape learning...I now 'know myself more' because of reflecting on my teaching...FCP helped me consider the TPI questions more deeply and with better understanding...more comfortable in dealing with issues of values...the TPI increased my awareness that my beliefs should influence my teaching practices.

While data did not specifically point to any one singular reflection activity (Table 1), that influenced change, more often than not, shifts in perspective were attributed to the various levels of social negotiation that took place during discussions on critical teaching and learning issues between participants within the FCP cohort experiences.

...interactions with cohort members helped to shape and deepen my beliefs about teaching and learning ... caused me to think outside my own "teaching world"... emphasis on diversity of learning/teaching philosophies...inter-relationships with other cohort members...exchange of experiences...how to turn a series of questions into a group discussion.

Nine participants reported stable TPI scores from pre to post FCP. Comments from these participants suggest that the FCP learning experiences reinforced their perspective of teaching and inspired them to apply similar reflective activities within their own classrooms. 
... [the FCP] "increased my use of active learning and higher order questioning strategies in my classroom... provided opportunities to think about my teaching... through workshop processes and discussions...gave me a general set of principles from the readings and workshops...made me more assertive in my beliefs through an increase in my understandings of theories in education and feedback from all the assignments... increased my reflection on my teaching - action research assignments were good for me.

When particular FCP learning experiences were attributed to creating pre-post TPI change scores, these did tend to depend upon one's specific perspective of teaching. For example, increases in Developmental Perspective scores were very much in line with the FCP intentions to engender a community of practice and reflection about university teaching and learning issues. For example:

... [the FCP] "validates this perspective most of all... has made me consider the students' point of view of teaching and learning...I have increased the use of case studies in my classes from various workshop ideas.

Increases in Nurturing Perspective scores tended to be attributed to FCP activities that focused on learner's needs. For example"

...the peer-review of teaching practices assignments made me less serious and more connected with my students...I have shifted more toward learning-centred approaches with a course syllabus with learning objectives, active learning and critical thinking strategies in my classes.

while increases in Social Reform Perspective scores tended to be attributed to 'bigger picture' issues and discussions that took place within the FCP. For example:

...workshop discussions dealt a lot with values which caused me to think outside my own faculty and teaching world...the learning [inclusion/diversity] frameworks increased my awareness of the importance of "social context.

The Canadian Journal of Higher Education

Volume XXXV, No. 3, 2005 
These data lend support to the importance of faculty learning communities in influencing positive pedagogical change, as well as the need for a wide range of reflection activities within the context of crossdisciplinary faculty development programs.

\section{What are the barriers to facilitating reflection for a cross-disciplinary faculty cohort?}

For many faculty members the request to reflect critically on their teaching was an unfamiliar and daunting task, requiring them to articulate what they normally take for granted -- their beliefs about knowledge and learning and the implications these have for their roles as a teachers. Thus FCP participants asked many questions. For example, "What is it that one should reflect upon?", "How are the underlying values and assumptions to be identified?", and once identified, "how are those values and assumptions to be (re)considered?". In other words, the objects and processes of critical reflection were not self-evident to our participants. Indeed, it was something of a new experience for many participants to look not only at their approach to teaching, but to examine the very lenses through which they reflected on their teaching. Thus the Teaching Perspectives Inventory provided a starting point for critical reflection on the underlying assumptions and values that gave direction and justification to their work as university teachers.

An analysis of instructors' reflections and field notes throughout the eight-month FCP suggested that cohort members became progressively more engaged and comfortable with the demands and processes of reflection. As could be expected, some of these reflection activities worked better than others toward that end (Caffarella,\& Zinn, 1999). Many participants commented that the variety of reflective activities were 'very useful' to them in terms of 'habitualising' the process of reflection through diverse and on-going teaching and learning experiences. Several respondents, however, expressed general concern about the 'excessive quantity' of reflection activities that were required throughout the FCP. Particular challenges that tended to hinder reflection included inadequate time allocation, insufficient clarity and goals for authentic reflection, and lack of cultural norms for reflective teaching practices within academe. For 
example, a number of cohort members expressed a preference for more time to be allotted to reflection assignments within program time versus completing reflections outside of program time. Reflection activities were not always prioritised for some participants beyond "doing activities in the program". Consequently, they were not always performed as intended i.e. weekly journal entries were intended to be completed on returning to their office, prior to answering phone messages, e-mails or a long list of other pending academic tasks.

Several cohort members did not complete the full range of required reflection activities. Some people could not keep up with the weekly journal and consequently it became a meaningless task of 'catch-up'. In the case of missed journal entries, participants were advised to consider an overall reflection (if appropriate) of key themes over any given period. A number of cohort members expressed a desire for more structure and clarity for the quality and quantity of reflection. For example, weekly journal reflection expectations (and rationale) were not clear to some cohort members. At times this left faculty members more confused, although others appreciated the flexibility to construct reflections to suit their learning needs. Finally, several cohort members expressed some difficulty providing adequate critique to other faculty members during peerfeedback assignments, as well as guidelines for self-reflection to improve their teaching dossiers. These latter concerns tended to focus on 1) 'who' would be reading the assignments, 2) being sensitive to prevent an overly positive or negative critique, and 3) the awkwardness and unfamiliarity of engaging in a completely alien activity as part of their teaching practice in higher education. These data lend further support to the importance of prior learning assessment when designing reflection activities (quality and quantity) to suit the diverse needs and circumstances of individual faculty cohort members. Evident by portfolio documentation on the scholarship of teaching and learning, as well as through the progressive quality of FCP cohort discussion forums over the eight-month period, in general FCP cohort members did develop impressive abilities and skills pertaining to reflective teaching practices.

The Canadian Journal of Higher Education Volume XXXV, No. 3, 2005 


\section{CONCLUSION}

This article examines whether and how theoretical constructs of reflective practice were applied with a diverse cohort of university teachers in a faculty certificate program on teaching and learning in higher education. The TPI provided a valuable reflective tool for faculty to analyse their beliefs, intentions and actions toward teaching. Clearly, a major benefit of the TPI in this context is that it provides a peer-review opportunity which is the traditional hallmark of scholarship and implicit within the scholarship of teaching and learning. Furthermore, it was used as an effective pre-post program measure of change associated with reflection on teaching.

Data from this study indicate that cross-disciplinary university teachers enrolled in a cohort-based faculty development program possessed multiple, rather than a singular perspective of teaching. Despite a relatively small sample size for these two years' FCP cohorts, this study suggests that faculty development programs such as this can result in positive changes in a faculty member's perspective on teaching. A change in faculty members' TPI scores indicated that university teachers reflected more deeply on their underlying pedagogical beliefs, intentions and actions at the end of the FCP, than they did at the beginning. The use of TPI data, however, should be interpreted cautiously since this instrument is a quantitative attempt to capture an otherwise complex and contextually-bound teaching and learning process. Furthermore, the use of the TPI is related to its particular role in the larger context of activities meant to engender reflection.

Data did not specifically point to any one reflection activity (as described in table 1) that was more efficacious for reflection than the rest. For the most part, shifts in beliefs were attributed to the levels of social negotiation that took place during discussions on critical teaching and learning issues between professors from a wide range of disciplines and academic ranks within the FCP cohort. Thus the value of any single reflection activity within a faculty development program is importantly related to how it is embedded in the larger context of teaching and learning experiences that are meant to engender reflection. Therefore, in order to meet the diverse needs and circumstances of university teachers, a wide range of individual and collaborative reflective activities are required that 
vary in such dimensions as qualitative and quantitative, individual and collaborative, time frame, and the degree of structure. Furthermore, when facilitating reflective practices, this study suggests that faculty developers should (1) pay particular attention to the 'bigger picture' of institutional 'norms' in which faculty are situated, (2) work toward developing an academic culture that values reflective teaching practices; (3) ensure that there is adequate time for reflection within the context of a faculty development program; and finally, (4) through individualised prior learning assessment, develop clear expectations and goals for reflection experiences (quality and quantity) that ideally build toward a summative document or an appropriate assignment that helps integrate reflective activities.

This study contributes to a growing body of evidence-based pedagogy in higher education and provides critical insights for faculty developers pertaining to the design of responsive learning experiences for reflection. Further research is required with larger FCP sample sizes to investigate the specific efficacy of individual reflection tools, as well as the longer-term impacts of FCP's on reflection practices for cross-disciplinary university teachers.

The Canadian Journal of Higher Education

Volume XXXV, No. 3, 2005 


\section{References}

Altrichter, H., Posch, P., and Somekh, B. (1995). Teachers Investigate their Work: An Introduction to the Methods of Action Research. Routledge Publishers.

Angelo, T.A., and Cross, K.P. (1993). Classroom Assessment Techniques: A Handbook for College Teachers. San Francisco: Jossey-Bass, 58-59.

Barab, S.A., and Duffy, T. (2000). From practice fields to communities of practice. In D. Jonassen and S.M. Land (Eds.). Theoretical Foundations of Learning Environments (pp. 25-56) Mahwah, NJ:Erlbaum Press.

Baum, C., and Baum, D. (1996). A national scheme to develop and accredit university teachers. The International Journal for Academic Development, 1(2), 51-58.

Bogdan, R. C. and Biklen, S. K. (1992) Qualitative research for education: An introduction to theory and methods. Boston: Allyn and Bacon

Bowman, M. (1997). "Metaphors We Teach By: Understanding Ourselves as Learners." Teaching Excellence, 8,3.

Boyer, E. (1990). Scholarship reconsidered: Priorities for the professoriate. Princeton, NJ: The Carnegie Foundation for the Advancement of Teaching.

Brew, A., and Boud, D. (1996). Preparing for new academic roles: A holistic approach to development. The International Journal for Academic Development, $1(2), 17-25$.

Brookfield, S.D. (1995). Becoming a Critically Reflective Teacher. San Francisco: Jossey-Bass publishers.

Caffarella, R., and Zinn, L. (1999). Professional development for faculty: A conceptual framework of barriers and supports. Innovative Higher Education, 23, (4), 241-254.

Cranton, P. (2001). Becoming an Authentic Teacher in Higher Education. Malabar, Florida: Krieger Publishing Company.

Cunsolo, J.M., Elrick, M., Middleton, A.L.A., and Roy, D. (1996). The scholarship of teaching: a Canadian perspective. Canadian Journal of Higher Education, 26, pp. 35-56.

Day, R, Robberecht, P., and Roed, B. (1996). Teaching Dossier: A Guide. University Teaching Services, University of Alberta, Edmonton.

Gibbs, G. (1998). The Preparation of university teachers in Europe and Australasia. In J. Forrest-Campion (Ed.), University Teaching: International Perspectives, Boston: Brock. 
Harper, V. (1996). Establishing a community of conversation: Creating a context for self-reflection among teacher scholars. In Richlin and D. Dezure (Eds.), To Improve the Academy, 19, (pp.251-266). Bolton, MA: Anker

Hinett, K., and Thomas, J. (1999). Staff Guide to Self and Peer-Assessment. The Oxford Centre for Staff and Learning Development, Oxonian Rewley Press Ltd.

Hubball, H.T., and Poole, G. (In press). A learning-centred course on university teaching. International Journal for Academic Development.

Hubball, H.T., Clarke, A., and Beach, A. (2004). Assessing Faculty Learning Communities. In M.D. Cox and L. Richlin (eds.) Building Faculty Learning Communities. New Directions for Teaching and Learning (the "Journal"), 97, 87100 .

Hubball, H.T., and Levy, A (2004). Graduate Course Design in Health Care and Epidemiology A Learning-Centred Approach. Journal for Faculty Development, 20 (1).

Jay, J.K., and Johnson, K.L. (2002). Capturing complexity: A typology of reflective practices for teacher education. Teaching and Teacher Education, 18(1), 73-85.

Keesen, F., Wubbels, T., Van Tartwijk, J., and Bouhuijs, P.A.J. (1996). Preparing university teachers in The Netherlands: Issues and trends. The International Journal for Academic Development, 1(2), 8-16.

Kreber, C. (2001). Conceptualizing the scholarship of teaching and identifying unresolved issues: The framework for this volume. New Directions for Teaching and Learning, 86, 1-18.

Kreber, C., and Cranton, P. (2000). Exploring the scholarship of teaching. The Journal of Higher Education, 71(4), 476-495.

Lincoln, Y.S. and Guba, E.G. (1985). Naturalistic Inquiry. Beverly Hills, California: Sage.

Loughran, J.J. (2002). Effective reflective practices: In search of meaning in learning about teaching. Journal of Teacher Education, 53(1), 33-43.

McKeachie, W.J. (1997). Critical elements in training university teachers. The International Journal for Academic Development, 2(1), 67-74.

Mills, G. E. (2000). Action Research: A Guide for the Teacher Researcher. Upper Saddle River, New Jersey: Merrill Prentice hall.

O’Neil, C, and Wright, A. (1998). Recording Teaching Accomplishment: A Dalhousie Guide to the Teaching Dossier, 5th Edition. Office of Instructional Development and Teaching. Dalhousie University, Halifax, Nova Scotia.

The Canadian Journal of Higher Education Volume XXXV, No. 3, 2005 
Pratt, D.D. (2002). Good teaching: One size fits all? In Jovita Ross-Gordon (Ed.) An Update on Teaching Theory, San Francisco, Jossey-Bass.

Pratt, D.D. (1998). Five Perspectives on Teaching in Adult \& Higher Education. Malabar, FL: Krieger Publishing.

Pratt, D.D. (1997). Reconceptualizing the Evaluation of Teaching in Higher Education. Higher Education 24, 23-44.

Pratt DD. (1992). Conceptions of teaching. Adult Education Quarterly, 42, 203-220.

Pratt, D.D, and Collins, J.B. (2000). The Teaching Perspectives Inventory, http://www.teachingperspectives.com/PDF/development1.pdf. Proceedings of the $41^{\text {st }}$ Adult Education Research Conference Vancouver, B.C.

Rust, C. (1998). The impact of educational development workshops on teachers' practice. The International Journal for Academic Development, 3(1), $72-80$.

Seijts, G., Taylor, L., and Latham, G. (1998). Enhancing teaching performance through goal setting, implementation and seeking feedback. International Journal for Academic Development, 3(2), 156-167.

Schön, D. (1987). Educating the reflective practitioner: Towards a new design for teaching and learning in the professions. San Francisco: Jossey-Bass.

Smith, R.A. (1995). Creating a culture of teaching through the teaching portfolio. Journal on Excellence in College Teaching, 6(1), 75-99.

Smyth, W.J. (1992). Teachers' work and the politics of reflection. American Educational Research Journal, 29(2), 267-300.

Wildman, T., Hable, M., Preston, M., and Magliaro, S. (2000). Faculty student groups: Solving "good problems" through study, reflection, and collaboration. Innovative Higher Education, 24,(4), 247-263

Yost, D.S., Sentner, S.M., and Foulonza-Bailey, A. (2000). An examination of the construct of critical reflection: Implications for teacher education programming in the $21^{\text {st }}$ Century. Journal of Teacher Education, 51(1), 39-49.

The Canadian Journal of Higher Education Volume XXXV, No. 3, 2005 